NORDIC MUSEOLOGY 2020 • 1, S. 23-41

\title{
Hva kommuniseres i forfattermuseer?
}

\author{
JOHAN SChimANSKI Og UlRIKe SPRING
}

Title: What do writers' museums communicate?

\begin{abstract}
Writers' museums often privilege the biographical person of the author rather than their literary works. Here we present a model which can be used not only as a method of analysis, but also as as an inspiration that can help create productive tensions in the exhibition of biography and works in author museums. Our departure point is that the writer's museum is a double act of communication, or more precisely a museal act of communication about a literary act of communication. Using Roman Jakobson's model of the communicative act, we show how museums make visible or hide different parts of the communications network, as well as what complicates this network. We use examples from the Strindberg Museum in Stockholm throughout to make an abstract argument more concrete, referring to other museums and exhibitions to provide breadth where solutions and traditions are concerned.
\end{abstract}

Keywords: writer's museums, communication acts, semiotics, Strindberg Museum, Roman Jakobson.

Om forfattermuseer er kommunikative handlinger, hvem er det som kommuniserer $h v a$, ved hjelp av hva, til hvem i forfattermuseer? Forfattermuseenes grunnleggende spenning ligger i vektleggingen av biografi kontra litteratur, altså hva de skal kommunisere. Vårt gjennomgående eksempel her, Strindbergsmuseet i Stockholm, har sitt utgangspunkt i August Strindberg (1849-1912) som biografisk person. Samtidig får den besøkende oppleve det Strindberg er mest kjent for, litteraturen han skrev, samt ideene hans og hvordan han har blitt brukt i ettertiden (sml. Bohman 2012:108f.). I forfat- termuseer er fokus delt mellom personen og litteraturen, og oftest er det personen som får mest plass. Dette gjelder ikke minst de musealiserte forfatterhjemmene, som vi gir særlig oppmerksomhet til her. De domineres ofte av biografiske fortellinger og personlige objekter (sml. Lund 2016). Det er forfattermuseenes paradoks at selve litteraturen, grunnen til at forfatteren har oppnådd den kulturelle verdien som gjør henne eller ham et museum verdig, er vanskeligere å formidle musealt.

Men for forfattermuseene er spørsmålene fra hvem, til hvem og med hva mer komplekse 
enn de ser ut til. Den internasjonale forskningen omkring forfattermuseer utføres i stor grad av litteraturvitere og museologer som har vært opptatt av museenes historie og koblinger til forfatterne, samt av turismeforskere som har undersøkt de besøkendes motivasjon for å dra på museum. Vi mener at vi kan få en bedre forståelse av sammenhengen mellom museum, litteratur, forfattere og besøkende ved å kartlegge forfattermuseet som en dobbel kommunikativ handling. Det innebærer at kommunikasjonen skjer fra museumsprodusenter, gjennom museet og til de besøkende, samtidig som museet handler om kommunikasjon fra forfattere, gjennom litteratur og til leserne (fig. 1). Men disse kommunikative handlingene kan ikke reduseres til enkle enveisprosesser; de vikles inn i hverandre og går i ulike retninger. Museets forestillinger om de besøkende (eventuelt med grunnlag i tilbakemeldinger og undersøkelser) virker tilbake på museet og på framstillingen av forfatteren/litteraturen. Ved å se disse sammenhengene og få fram elementer som ofte underkjennes i forskningen rundt forfattermuseer, kan vi forstå bedre de valgene som har ført til at museene har fått den formen de har, samt oppdage muligheter til nye fokus i museene.

Museer skal kommunisere. Det finnes ulike tilnærminger til utstillingene og kommunikasjonsprosessene som foregår i disse, først og fremst med utgangspunkt i semiotiske modeller (f.eks. Scholze 2004, Hoffmann 2018), og i de senere årene også nettverksanalyser (f.eks. Gosden \& Larson 2007, Waller 2017). Semiotiske analyser gir oss nødvendig innsikt i potensielle tolkninger av gjenstander og hvordan plasseringen i museumsrommet frembringer bestemte budskap. De gjør det enklere å forstå hvordan museer kommuniserer budskapet til de besøkende ved hjelp av plasseringen i rommet og utvalget av gjenstan-

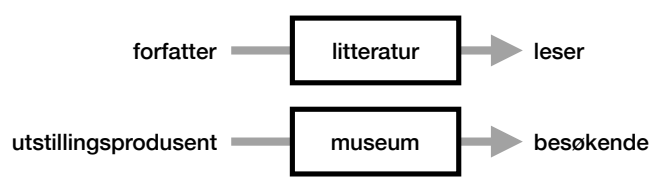

Fig. 1. Den doble kommunikative handlingen $i$ forfattermuseer.

der, tekster, farger, interaksjonsmuligheter osv. Fordelen med nettverksanalyser inspirert av aktør-nettverksteori (ANT) og materialitetsteorier, er at de fokuserer på forholdet mellom ulike materielle og immaterielle, menneskelige og ikke-menneskelige aktører, og derfor kan synliggjøre uventede forbindelser og brudd. De kan forklare hvorfor kommunikasjonsinnsats noen ganger ikke lykkes, og andre ganger lykkes på en annen måte enn forventet. Fokuset går fra gjenstand, tekst og rom til prosess og relasjon og videre til gjøren (Damsholt \& Simonsen 2009, Aarbakke 2019).

Her foreslår vi å utvide disse tilnærmingene ved å gå tilbake til den ofte brukte modellen for kommunikative handlinger utviklet av språkforsker, litteraturteoretiker og semiotiker Roman Jakobson (1978 [1960]). Når vi har valgt å anvende en flere tiår gammel semiotisk modell på forfattermuseer, har de nye ANT-inspirerte tilnærmingene med sin interesse for det flerstemte, relasjonelle og prosessaktige vært av stor betydning (ANT er forøvrig delvis inspirert av semiotikken, sml. Latour 2005:54f., fn. 54-55). Jakobsons modell, med sine elementer (eller aktører) og koblinger, gir en forenklet framstilling av de komplekse kommunikasjonsnettverkene som forfattermuseer inngår $i$.

Vi er videre inspirert av to teoretikere, Jana Scholze og Anna Rebecca Hoffmann, som har forsøkt å typifisere strukturene som rammer inn kommunikasjonsprosessen i museumsutstillinger. Som et ledd i museenes med 
hva muliggjør og begrenser disse strukturene spørsmålene hva og til hvem. I sin semiotiske analyse av fire europeiske kulturhistoriske museer tar Scholze utgangspunkt i utstillingenes "paradigmatiske presentasjonsformer" (Scholze 2004:29, vår oversettelse): klassifisering, kronologi, iscenesettelse og komposisjon, som ofte forekommer i kombinasjon. Klassifisering viser til den tradisjonelle, Linné-inspirerte utstillingsformen der gjenstander grupperes etter funksjoner, typer og likheter; kronologi blir ofte brukt av historiske museer når de strukturerer utstillinger; iscenesettelse omfatter bl.a. dioramaer, rekonstruerte historiske scener og historiske hus; mens komposisjon sammenstiller forskjellige gjenstander og elementer for å skape nye koblinger og fortellinger.

I sin analyse av tyske forfattermuseer foreslår Hoffmann også andre presentasjonsformer som tar utgangspunkt i utstillingen som helhet: historisk iscenesettelse, littercer iscenesettelse, kronologi og tematiske moduler (2018:166). Skillet mellom historiske og litterære iscenesettelser er spesielt for forfattermuseer og henger sammen med spenningen mellom et hva som handler om forfatteren (og hennes livsverden), og et hva som handler om litteraturen. Mens Hoffmanns tre første former er bl.a. inspirert av Scholzes iscenesettelse og kronologi (2018:166, fn. 6), bryter hennes siste utstillingsform med iscenesettelser og biografiske kronologier og fokuserer heller på utvalgte aspekter av forfatterens liv og verk. Eksemplene hennes viser at tematiske moduler hovedsakelig forekommer i utstillinger som kommer i tillegg til de iscenesatte hjemmeinnredningene, eller plasseres inn i disse (2018:188-193). Vi vil mene at tematiske moduler bygger på en kombinasjon av Scholzes kategorier klassifisering (moduler inndeles etter temaer som ofte følger bestemte strukturer) og komposisjon (materialer plasseres innenfor modulene og viser til hverandre).
Hoffmanns kategori redegjør likevel på en mer direkte måte for både kuratorens valg av temaer, altså forfattermuseets $h v a$, og den besøkendes aktive deltakelse i utstillingen, forfattermuseets til hvem. Den besøkende plasserer modulene i sitt kunnskapsrom og kan også lage sin egen historie om forfatteren ved å velge å lese en modul eller utelate en annen (2018:192f.). I Strindbergsmuseet fungerer leiligheten som en historisk iscenesettelse, mens kronologi og tematiske moduler - den såkallte "basutställningen" (Bohman 2012:109, Strindbergsmuseet 2019), med tittelen "Strindberg i centrum" - er plassert i tilstøtende rom i det som tidligere var naboleiligheten. Modulene inneholder enkeltinnslag av litterær iscenesettelse.

Samtidig kan - som modellen for forfattermuseet som en dobbel kommunikativ handling viser - skillet mellom "historisk" (dvs. biografisk, forfatteren som historisk person) og "litterær" utvides til å gjelde ikke bare iscenesettelse, men også andre presentasjonsformer. Fortellingen om Genji-museet utenfor Kyoto (der vi vet lite om den formodentlige forfatteren Murasaki Shikibus historiske liv) fokuserer på den litterære hovedpersonens liv og livsverden gjennom kronologier og tematiske moduler. Orhan Pamuks romanmuseum Museum of Innocence i Istanbul bruker på lignende måte litterære tematiske moduler.

Denne artikkelen kan forstås som et forslag til en metode som tar hensyn til både de litterære og de biografiske elementene i forfattermuseer. Selv om Scholze og Hoffmanns presentasjonsformer er svært nyttige som utstillingsanalyseverktøy, er det en risiko for at de bidrar til å bekrefte forskjellen mellom biografi og litteratur. Vi ønsker å utvide analysene av disse ved å tenke ut fra en uløselig sammenknytning mellom biografi og verk, og ved å ikke foreslå nye presentasjonsformer. I stedet ønsker vi at modellen vi presenterer 
fungerer og brukes som inspirasjon for museumsarbeidere og -forskere, og at den forhåpentligvis vil bidra til å skape produktive spenninger i utstillingen av biografi og verk $i$ forfattermuseer.

Når vi tar utgangspunkt i forfattermuseet som en dobbel kommunikasjonsakt, ønsker vi å vise hvordan Jakobsons modell for kommunikative handlinger kan brukes for å få fram hvilke deler av kommunikasjonsnettverket forfattermuseer gjør synlige, og hvilke de skjuler, samt hva som kompliserer dette nettverket. Artikkelen er ingen utstillingsanalyse, men vi bruker Strindbergsmuseet som gjennomgånde eksempel for å gjøre et abstrakt argument mer konkret. Museet, som drives av av en stiftelse, ble åpnet i 1973 og ligger på Drottninggatan sentralt i hovedstaden Stockholm, i bygningen Blå tornet, der Strindberg bodde i sine siste år. I dag kombinerer museet hans rekonstruerte leilighet med en større tematisk utstilling og forskjellige formidlingsaktiviteter, og tar dermed i bruk et stort utvalg kommunikasjonsstrategier. Ved behov henviser vi til andre museer og litterære utstillingsformer for å gi bredde når det gjelder museale løsninger og nasjonale tradisjoner.

\section{JAKOBSONS MODELL 1: MUSEALE KOMMUNIKASJONSHANDLINGER I FORFATTERMUSEER}

Scholze beskriver sine presentasjonsformer innenfor en semiotisk ramme, det vil si basert på en teori om kommunikasjon gjennom tegn, inspirert av Umberto Eco og Roland Barthes. Ifølge henne finnes det tre måter å tolke koder i museet på (Scholze 2004:30-39): lesing for denotasjon (gjenstander refererer til hvordan de en gang ble brukt), lesing for konnotasjon (utstillinger gir ytterligere mening til gjenstander på bakgrunn av kunnskapen og erfa- ringene som er tilgjengelig for den besøkende), og lesing for metakommunikasjon (måten gjenstander blir presentert på kan fortelle oss hvilke ideologier og begrensninger et museum arbeider innenfor). Denne tilnærmingen legger vekt på gjenstandenes betydning, mens forskerne inspirert av nettverksanalyser er opptatt av menneskenes og tingenes tilstedeværelse og relasjoner til omverden (Mordhorst 2009). Kommunikasjonen oppstår gjennom disse relasjonene, og selve kommunikasjonsakten skaper et nettverk.

I sin modell identifiserer Jakobson ikke bare tre, men seks elementer som er til stede i enhver kommunikative handling (fig. 2). Det som er felles for de to kommunikative handlingene på forfattermuseer, slik de forestilles i vårt tidligere diagram, er at de skiller mellom det Jakobson kaller AVSENDER, MEDDELELSE og MOTTAKER. Disse suppleres med ytterligere tre elementer: KONTAKT, KODE og KONTEKST (1978 [1960]).

Ifølge Jakobson vil noen av disse elementene dominere $\mathrm{i}$ de fleste kommunikative handlinger, kanskje i en hierarkisk orden. Modellen i seg selv setter imidlertid ikke et bestemt element - for eksempel AVSENDER - foran de andre. Kommunikasjonshandlingen utgjør et nettverk der alle elementer interagerer, kan bidra til og potensielt bli hovedfokus. Innenfor litteraturvitenskapen finnes hele teoridannelser som kan sies å ha fokus på en bestemt element i modellen (f.eks. leser-respons-teori og Rezeptionsästhetik, med fokus på MOTTAKER, eller den historisk-biografiske metoden, med fokus på AVSENDER osv.).

Jakobsons termer er nøyaktig definert, men kan være forvirrende, da noen av dem kan brukes i andre, mer kjente sammenhenger. Det er avgjørende at MEDDELELSE-elementet hos Jakobson angår meddelelsens materielle form, ikke dens innhold. Meddelelsens innhold, det 


\title{
KONTEKST \\ referensiell \\ forfatter/tekster/historie
}

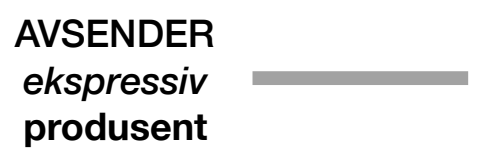
MEDDELELSE
poetisk
utstilling

MOTTAKER

konativ

besøkende

\author{
KONTAKT \\ fatisk \\ orientering
}

\section{KODE \\ meta-språklig \\ museologi}

Fig. 2. Jakobsons modell for kommunikative handlinger med ELEMENTER, funksjoner og museale elementer (tilpasset forfattermuseer).

meddelelsen meddeler eller viser til, kaller han dens KONTEKST, også en uvant ordbruk. Strindbergsmuseets MEDDELELSE er selve utstillingen (den rekonstruerte leiligheten og den tematiske utstillingen, samt forskjellige formidlingsaktiviteter, trykte materialer og nettsider); dets KONTEKST er Strindbergs livsverden, ideer og verker, samt mottakelsen hans. MEDDELELSEN i f.eks. Strindbergs Inferno er selve bokens tekst og uttrykk, mens KONTEKSTEN i denne selvbiografiske teksten er Strindbergs liv i Paris, Oberösterreich og Lund i perioden 1864-96, eksperimenter med alkymi, og erfaringer fra en ekteskapelig og psykologisk krise. Når Jakobson bruker termen KONTEKST, viser han ikke til det å bruke en bakgrunn for å forklare eller belyse et bestemt fokus (eller omvendt), som f.eks. når Strindbergsmuseets nettside forteller at den te- matiske utstillingen - med tittel "Strindberg i centrum" - "placerar författaren i en kontext" (Strindbergsmuseet 2019). KONTEKST handler mer om valg av fokus: KON(-)TEKSTEN er det "teksten" viser til.

Jakobson knytter dessuten hvert element til en spesifikk funksjon som kan hjelpe oss å forstå modellen videre. Jakobson kaller MEDDELELSENS funksjon den poetiske funksjonen fordi han tar utgangspunkt i når en språklig kommunikasjonshandling er fokusert på sitt eget materielle uttrykk (rim, gjentakelse, ordvalg osv.), og dermed blir poetisk. Flere av funksjonsbetegnelsene er nokså tekniske og forklares nedenfor. For å unngå forvirring har vi plassert Jakobsons elementer i store bokstaver og tilhørende funksjoner i kursiv, slik at de er tydelig merket som hans begrep og en del av en bestemt modell. 
I denne seksjonen anvender vi Jakobsons modell på forfattermuseet som en museal kommunikasjonshandling, i neste seksjon som del av en littercer kommunikasjonshandling. I artikkelens konklusjon tar vi for oss begrensningene i modellen og hvordan en fleksibel bruk av modellen kan hjelpe oss å forstå kommunikative handlinger på forfattermuseer som nettverk.

AVSENDER (ekspressiv funksjon): Når vi ser på museer (og ikke bare forfattermuseer) som kommunikative handlinger, kan vi identifisere den museale AVSENDEREN som kuratoren eller produsenten eller ofte et større antall mennesker og institusjoner, inkludert direktører, tekniske medarbeidere, designere, eiere, bidragsytere, finansielle bidragsytere osv. I et forfattermuseum kan også forfatteren være en del av den museale AVSENDEREN, hvis denne har vært involvert i planleggingen av museet før sin død (Hendrix 2008). Den ekspressive funksjonen vil fokusere på museumsprodusentenes behov og intensjoner, som ofte forholder seg til ideer om museers oppgave i samfunnet, identitetsbygging, tradisjoner knyttet til forfatterens status og forestillinger om litteraturens virkemåte. Den museale AVSENDEREN identifiseres noen ganger på en navnetavle, men er ofte skjult eller bare uttrykt på en implisitt måte.

Strindbergmuseet viser noe av denne kompleksiteten. AVSENDEREN for den faste tematiske utstillingen oppgis på et skilt i det første rommet og på innsiden av omslaget til en liten katalog (Strindbergsmuseet 2011). Tre personer står som produsenter og tekstforfattere: tidligere museumsdirektør, nåværende direktør og en nåværende "intendant". I tillegg navngis ansvarlige for "[f]orm och utställningsteknikk", "färgsättning och grafisk form, og "AV-teknik". Skiltet opplyser også om at utstillingen har fått midler fra en stiftelse.
Utspredd i den tematiske utstillingen kan den besøkende dessuten finne små bronseskilt som angir hvem som har bidratt med ulike gjenstander.

Man må til sekundærlitteratur og arkiver for å finne ut av andre deltakere på AVSENDER-siden, f.eks. de som har dokumentert leiligheten etter hans død og tatt vare på eiendelene hans (delvis oppbevart på Nordiska museet), Strindbergssällskapet, som ble etablert i 1945 med mål om å danne det nåværende museet, samt museumsarbeiderne fra Stockholms Stadsmuseum som begynte å rekonstruere leiligheten i 1971 (for detaljer se Söderström 1999, Bohman 2012). Antakeligvis har Strindberg tenkt at leiligheten skulle bli forfattermuseum (Bohman 2012:97) og dermed påvirket utgangspunktet. Andre som befinner seg på AVSENDER-siden er museets eiere, Stiftelsen Strindbergsmuseet, samt styrerepresentanter fra flere tunge kulturinstitusjoner knyttet til Strindberg, Stockholm og nasjonen Sverige. Personalet generelt vil også ha løpende innvirkning på museet som kommunikasjonsakt. I tillegg er AVSENDER-siden representert ved kunstnerne Ingrid Falk og Gustavo Aguerre, som har skapt en installasjon med Strindberg-sitater i gateoverflaten som leder opp bakken til museet. Et fokus på museal AVSENDER vil f.eks. være interessant om vi forsker på Strindbergsmuseets nasjons- og stedsbyggende funksjon, eventuelt dets transnasjonale dimensjoner.

MUSEAL MEDDELELSE (poetisk funksjon): I museal sammenheng vil MEDDELELSES-elementet vise til hvordan gjenstander, tekster, rom, omgivelser og levende mennesker (besøkende, guider, annet personale) opptrer som sanselige opplevelser, heller enn til hvilke meninger de formidler og er bærende for (Jakobsons KONTEKST). Den poetiske funksjonen til museet kan struktureres estetisk og utgjøre museets stil, og avgjøre om det (og dets 


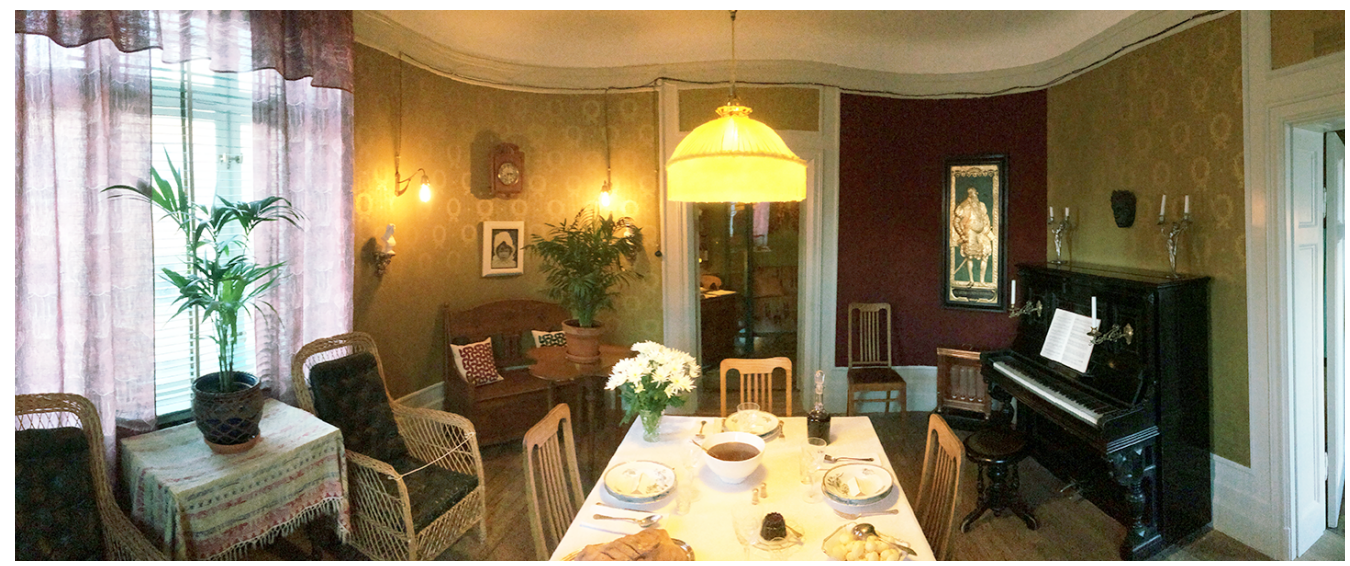

Fig. 3. Panorama av en del av interiøret i den rekonstruerte leiligheten i Strindbergsmuseet. Foto: Johan Schimanski og Ulrike Spring.

omgivelser) blir sett på som romantisk, sublimt, grotesk, moderne, postmoderne, kitsch osv.

Forfatterhjem kan være utformet av forfattere selv som uttrykk for en kunstnerisk estetikk, og dermed fokusere på den museale MEDDELELSEN; et kjent eksempel er Hugh Walpoles Strawberry Hill i London, som har en utpreget gotiske utforming (se Harald Hendrix' artikkel i dette spesialnummeret). Utstillingsdesignere kan være opptatt av de rent estetiske sidene ved utstillingene de er med på å lage. Et eksempel på et forfattermuseum med et sterkt fokus på det estetiske er Hamsunsenteret på Hamarøy i Nord-Norge, en svært slående bygning som er tegnet av en stjernearkitekt og gir utsikt over det sublime nordnorske landskapet. Bygningen har i tillegg både Knut Hamsuns kropp og litterære verk som KONTEKST, med lekne detaljer som gjenspeiler ansiktstrekkene hans og motiver i verkene. Den muliggjør en estetisk opplevelse av landskapet rundt, samtidig som den er settingen til mange av Hamsuns senere litterære verk og dermed også fungerer som KONTEKST. Men en kan godt besøke senteret bare for å oppleve arkitekturen og den sublime utsikten den gir til det omkringliggende landskapet (se også Egelands analyse i dette spesialnummeret).

MEDDELELSES-elementet i Strindbergsmuseet trer fram i den bevisste, moderne designen og fargebruken i den tematiske utstillingen og i opplevelsen av den iscenesatte leiligheten (fig. 3), med dempet lyssetting, nyklassisk/nyromantisk stil og et velordnet skrivebord, samt i kontrastene til det mer groteske toalettet og hostelydene på et lydspor aktivert av de besøkendes bevegelser. Men i både den tematiske og den iscenesatte delen har disse elementene også andre funksjoner: I den tematiske utstillingen skaper de en KODE som gjør at den besøkende kan skille mellom forskjellige tematiske moduler og dimensjoner, og i leiligheten har de en sterk KONTEKST-relevant funksjon der de viser til Strindbergs delvis borgerlige liv og aldrende kropp.

MUSEAL MOTTAKER (konativ funksjon): Den museale MOTTAKEREN er først og fremst de besøkende som museet er (mer eller mindre) tilpasset til. Museer fokuserer på 


\section{JOHAN SCHIMANSKI Og ULRIKe SPRING}

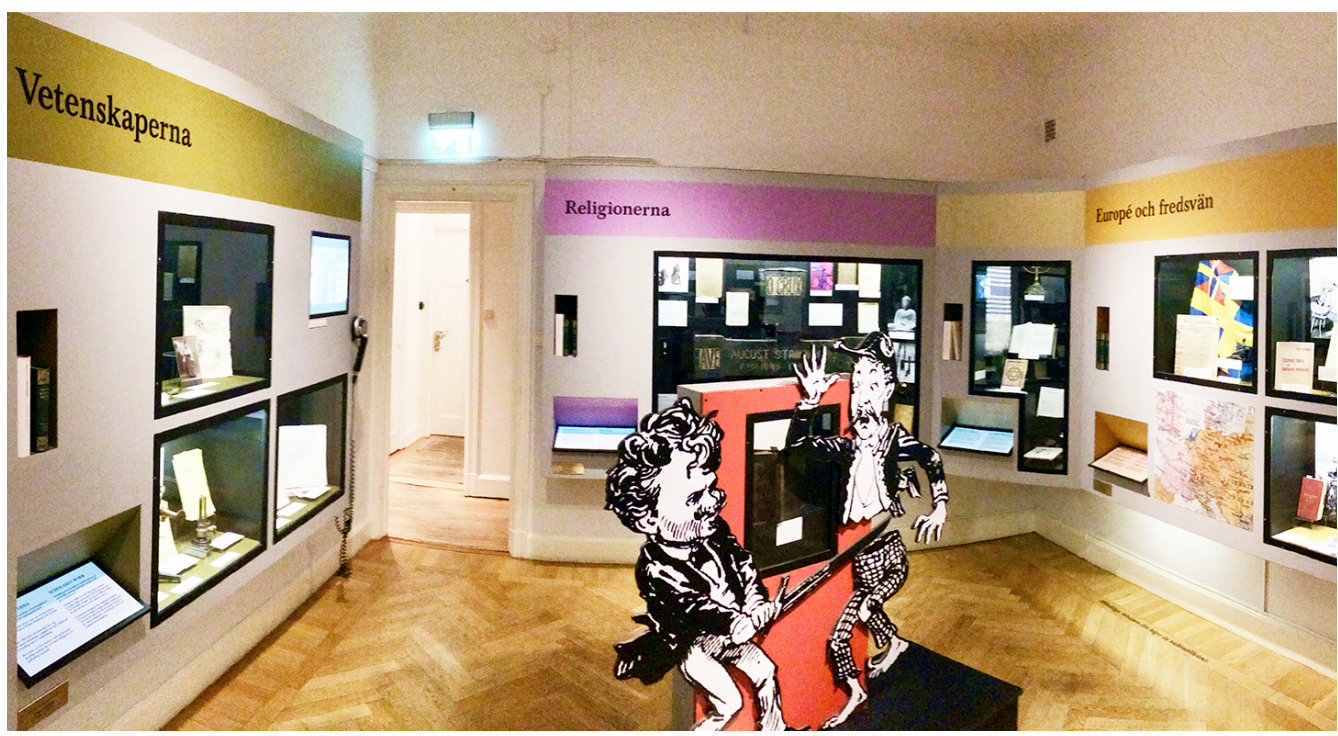

Fig. 4. En del av den tematiske utstillingen på Strindbergsmuseet, med fargekodete moduler. Foto: Johan Schimanski og Ulrike Spring.

besøkende og fungerer konativt (opprinnelig et filosofisk begrep som viser til det som tilstrebes $\mathrm{i}$ en handling) når de tar rollen som valfartssted, men kan også fungere som pedagogiske institusjoner eller opplevelsessentre. Litterære museer kan forsøke å tilpasse seg forventningene til de besøkende. I de fleste forfatterhjemmuseer ønsker sistnevnte (som litterær pilgrim) kanskje å oppleve auraen fra forfatterens fraværende kropp, eller (som mer tilfeldig turist) å lære mer om forfatteren og styrke sin kulturelle dannelse (sml. Nath \& Saha 2017:118f.). Museet kan også forsøke å "avfamilialisere" de besøkende, ved å utfordre deres forventninger og etablerte myter eller ved å tilskrive dem visse antakelser og holdninger og dermed "ideologisere" dem, noen ganger skjult bak tilsynelatende nøytralitet og objektivitet (sml. Scholze 2004:36).

Strindbergsmuseet i Stockholm er ikke bare tenkt som et valfartssted, men skal også utvide våre forestillinger om Strindberg. Den tematiske utstillingen motvirker at Strindberg reduseres til et svensk ikon, en berømt dramatiker, et symbol på en konservativ kanon og tilsynelatende misogyn, ved å tydeliggjøre den generiske variasjonen og bredden i Strindbergs produksjon, hans kritikk av patriotiske verdier, hans sosiale radikalisme og kompleksiteten i hans syn på kvinner.

De besøkende på et forfattermuseum er en sammensatt gruppe mennesker som kan være lokale (f.eks. skolebarn) eller transnasjonale (f.eks. turister). De reelle besøkende kan avvike fra målgruppene som er underforstått i utstillingen. Det kan hende at de ikke føler seg hjemme i museet. Atanu Nath og Parmita Saha (2017) antyder at motivasjonen til de besøkende ofte kan være mer kompleks enn den tradisjonelle utforminger av forfatterhjemmuseer legger opp til. Besøkende kan være fans av forfatteren, eller se besøket som en form 
for selvforbedring, en kilde til estetisk nytelse, eller en fritidsaktivitet for familie eller venner. MOTTAKEREN er sentral i forståelsen av museet som en demokratisk og inkluderende, men også potensielt ekskluderende institusjon.

MUSEAL KONTAKT (fatisk funksjon): En av de viktigste bekymringene til museumsdirektører er å få inn besøkende; museal KONTAKT er derfor viktig i museer. I språkvitenskapen er fatiske utsagn ytringer som først og fremst har til formål å holde samtalen gående, som når vi snakker om været i mangelen på noe annet å si. I museer finnes det elementer som skaper kontakt eller relasjoner med de besøkende, orienterer dem og trekker dem gjennom utstillingen. Stier, døråpninger, trapper, vegger, vesker, skilt, piler, instruksjoner, nummer (f.eks. til lydguidestasjoner), fortellinger og tau fører de besøkende fra rom til rom. I bevarte og rekonstruerte hjem skapes det bevegelsesruter der det opprinnelig ikke var noe fast bevegelsesmønster, for å sikre at den besøkende ser hele utstillingen. Omvisere og vakter bestemmer og opprettholder kontakten med utstillingen gjennom muntlige fortellinger og tilstedeværelse.

I den tematiske delen av Strindbergsmuseet rammes utstillingen inn av rom i veggen og innebygde glasskap. Den besøkende føres fra tema til tema ved hjelp av farger og overskrifter og går i sirkel med klokken, med et par avstikkere. Ved vårt første besøk i 2014 opplyste et lite papirskilt festet til en dørkarm at "Utställningen fortsätter $/ \rightarrow$ ". KONTAKT-elementet skaper mulighet for kommunikasjon ved å holde fast den besøkendes blikk og inviterer til - eller forhindrer - bestemte former for kroppslig bevegelse.

Museer generelt kan kobles til KONTAKT-elementet på et dypere nivå, fordi oppgaven deres er å beskytte og bevare kollektive minner og kulturarv for kommunikasjon til framtidige besøkende. Den konserverende dinåværende og framtidig KONTAKT. Strindbergsmuseet oppfyller sin rolle som konserverende museum, ikke bare gjennom det bevarte interiøret i Strindbergs siste bosted, men også gjennom en omfattende samling av gjenstander. Bøker, malerier, brev, presseklipp, fotografier osv. gjøres synlige i hele det fysiske museet, men er også tilgjengelige utenfor museet, i form av fotografiske databaser på museets nettsted. Besøkende ved det fysiske museet kan åpne og lese Strindbergs bøker i den tematiske utstillingen, og bøker i museets bibliotek Strindbergiana kan leses av forskere i museet. Publikum utenfor museet, uansett hvor de er i verden, kan også få tilgang til bøkene i Strindbergs samling - og hans margnotater - på nettstedet. Stiftelsen Strindbergsmuseet garanterer for at museet og dets samlinger bevares for framtiden.

MUSEAL KODE (meta-språklig funksjon): Jakobsons begrep meta-språklig bør kanskje reformuleres som "meta-museal" når det er snakk om museer, og tilsvarer Scholzes "metakommunikasjon" (Scholze 2004:35-39). KODE kan referere til de museologiske konvensjonene som deles av kuratorer og de besøkende, og som implisitt er til stede i alle museer. En KODE kan også skapes underveis i et museum: Farger brukes for å skille mellom forskjellige tematiske moduler; at rosa betyr Strindbergs forhold til kjønn (modulen "Kvinna - man") i Strindbergmuseet er en høyst flyktig KODE. De besøkende bruker slike KODER for å forstå og oppleve utstillingene. Når vi besøker et museum, må vi ha en idé om hva et museum er, og hvordan det bruker forskjellige presentasjonsmåter (deriblant iscenesettelser, kronologier, klassifiseringer, komposisjoner og tematiske moduler).

Tidligere direktør ved Strindbergsmuseet, 
Stefan Bohman, har bidratt til å utvide den museale KODEN i Sverige med sine bøker om museer, nasjonsbygging, arv og kanonisering i biografiske museer (1997, 2010; Bohman \& Palmqvist 2003), utgitt før og under engasjementet hans med Strindbergsmuseet. Han har dessuten redegjort for deler av den museale KODEN bak den tematiske utstillingen ved museet, i sammenheng med hvordan han ellers tenker om museer (Bohman 2012).

MUSEAL KONTEKST (referensiell funksjon): Tenker vi at museer er et produkt av en opplysningsdiskurs og har som mål å formidle kunnskap, er museal KONTEKST det mest sentrale elementet. Museer skal stort sett vise til noe. Kunstmuseer har som mål å dra oss vekk fra KONTEKST og tilbake til MEDDELELSE. Den kunstneriske MEDDELSELSEN, kunstverket, er påtakelig til stede og til å oppleve i kunstmuseer. Det er vanskelig å gi f.eks. litterære verk samme posisjon på museer; de kan nytes som MEDDELELSER andre steder enn på muset, og det er kanskje slik de nytes best.

KONTEKST blir dermed sentral for spørsmålet om forfattermuseets hva. Vi vil dessuten argumentere for at museal KONTEKST på forfattermuseet handler om vektlegging av elementer i den litterære kommunikasjonshandlingen. Som vi antydet innledningsvis, er forfattermuseets hva oftest den littercere AVSENDEREN, forfatteren og hennes livsverden, supplert av den littercere MEDDELELSEN, forfatterens litterære verk, og den litteræere KONTEKSTEN, den fiktive eller virkelige verden som formidles i forfatterens produksjon (en verden som kan falle sammen med deres livsverden). Således er Strindbergsmuseet typisk; det handler først og fremst om Strindberg som biografisk og tenkende person (litterær AVSENDER), men også om hans litterære produksjon (litterære MEDDELELSE) og de verdener vi kan oppleve i denne (litterær KONTEKST). Kan det også handle om de resterende elementene i den litterære kommunikasjonshandlingen?

\section{JAKOBSONS MODELL 2: LITTERARE KOMMUNIKASJONSHANDLINGER I FORFATTERMUSEER}

Hvis vi vil lære mer om hvordan litteraturmuseet vektlegger forfatter, litteratur, historisk bakgrunn osv., må vi altså analysere det som en littercer kommunikasjonshandling (fig. 5). Vi må spørre hvilket element i denne kommunikasjonshandlingen som dominerer den $\mathrm{mu}$ seale KONTEKSTEN.

LITTERÆR AVSENDER: I den litterære kommunikasjonshandlingen er AVSENDER vanligvis forfatteren, selv om den faktiske forfatteren ofte er gjemt bak en underforstått forfatter og noen ganger bak en lyrisk persona eller en prosaforteller, sistnevnte ofte ganske annerledes enn forfatteren. Mange litterære museer, inkludert forfatterhjem, fokuserer først og fremst på den litterære AVSENDEREN, da en idealisert versjon av forfatteren.

Tendensen til å privilegere forfatteren i litterære utstillinger ble fast etablert som del av1800-tallets feiring av genier. Det tradisjonelle forfatterhjemmuseet har fungert som den historisk-biografiske metoden som dominerte litteraturvitenskapen i denne epoken. Selv om hun ikke er til stede, er forfatteren hovedgjenstand for oppmerksomheten. I denne typen litteraturkritikk brukes den litterære produksjonen til å forstå forfatterens sinn og sosiale forhold, akkurat som forfatterens hjem brukes til å forstå og komme i kontakt med hennes liv. Mange lesere av litteratur og besøkende på litterære museer lar seg fascinere av forfatterens biografi fremdeles, selv når det er hennes verk som først har gjort inntrykk på dem. 


\title{
KONTEKST \\ referensiell \\ verden/handling/personer
}

$\begin{array}{ccc}\begin{array}{c}\text { AVSENDER } \\ \text { ekspressiv } \\ \text { forfatter }\end{array} & \text { MEDDELELSE } & \text { MOTTAKER } \\ \text { poetisk } & \begin{array}{c}\text { konativ } \\ \text { leser }\end{array}\end{array}$

\author{
KONTAKT \\ fatisk \\ genreprotokoll
}

\author{
KODE \\ meta-språklig \\ litteraturteori
}

Fig. 5. Jakobsons kommunikasjonsmodell med ELEMENTER, funksjoner og litterære elementer.

Når forfattermuseet er den dominerende formen for litteraturmuseer, blir det forfatteren som ofte knytter sammen en litterær produksjon. Spørsmålet er da hvorfor de fleste litteraturmuseer er forfattermuseer, og det kan hende at etablering av f.eks. nasjonale og regionale litteraturmuseer delvis vil dreie oppmerksomheten mot andre elementer i den litterære kommunikasjonshandlingen, selv om disse gjerne bruker forfatternes identitet og fødested som bindende prinsipp.

I Strindbergs leilighet fikseres det biografiske til perioden han bodde i leiligheten, nærmere bestemt ved det tidspunktet han døde (Bohman 2012:105). Historisk iscenesettelse vil ofte kollidere med en kronologisk forståelse av den litterære AVSENDEREN, fordi iscenesettelse krever gjenskapelse eller bevaring av et bestemt tidspunkt eller en fiksert blanding av elementer fra forskjellige tidspunkter. I de tematiske modulene motvirkes dette statiske inntrykket av den innledende kronologien i "basutställningen", samt av innslag fra hele Strindbergs liv. Ved vårt andre besøk, i 2019 (etter renovasjonen i 2017), var det kommet til en modul ("Stockholmaren") som fokuserte på Strindbergs mange forskjellige bosteder i Stockholm, i en sterk relativisering av fikseringen i leiligheten (fig. 6). Vektleggingen av iscenesettelse $\mathrm{i}$ mange forfatterhjemmuseer kan paradoksalt nok gjøre det vanskeligere å formidle viktige elementer i biografien deres: livsfaser og hendelser.

Den historiske iscenesettelsens logikk møter ofte et annet hinder i en annen grunnleggende biografisk spenning i forfattermuseet: det at li- 


\section{Johan SChimanski Og ULRIKE SPRING}

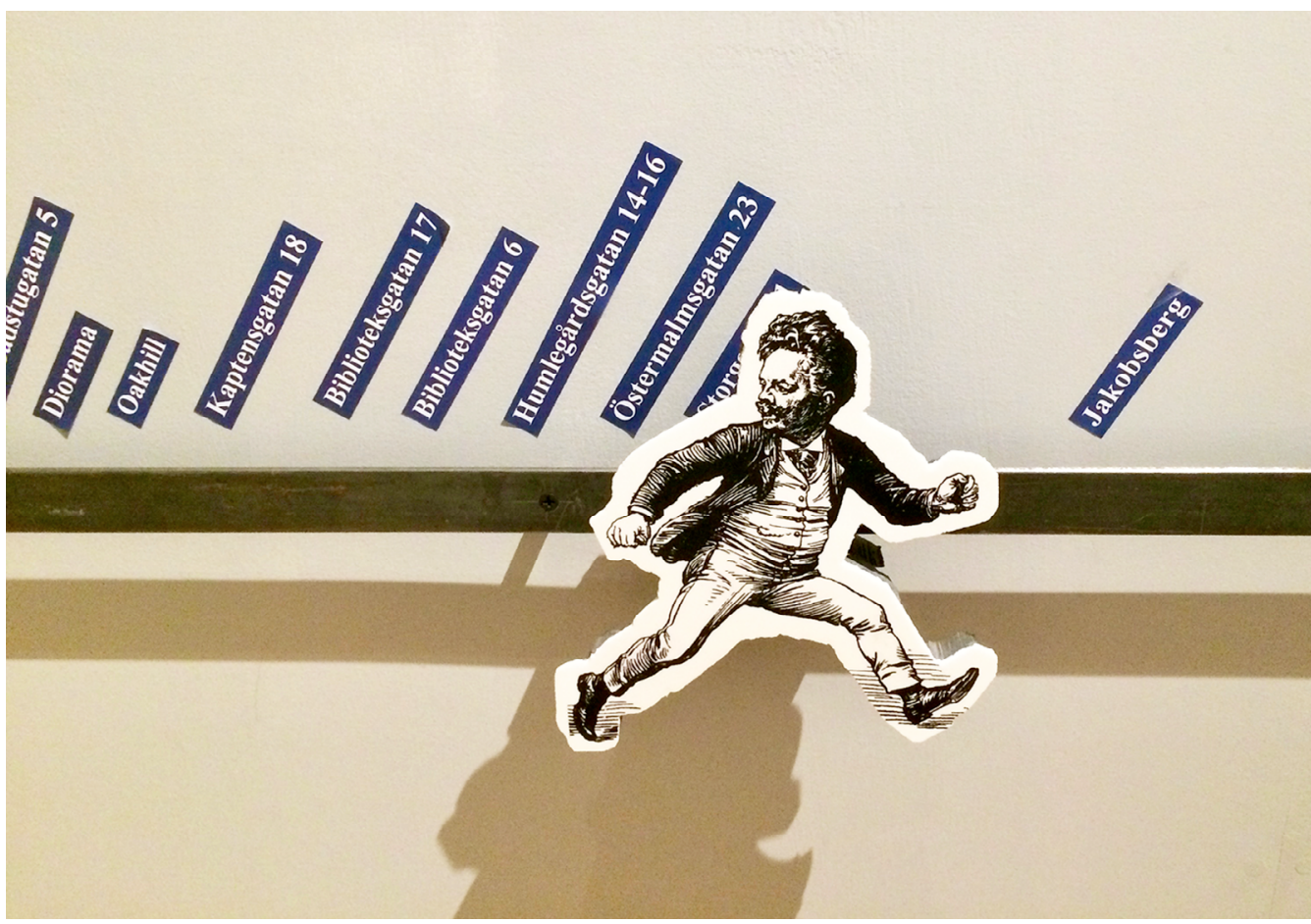

Fig. 6. Utsnittsbilde fra temamodulen "Stockholmaren" på Strindbergsmuseet. Foto: Johan Schimanski og Ulrike Spring.

vet og kroppen til den døde forfatteren bare kan formidles gjennom gjenstander og representasjoner. Den autentiske forfatteren er fraværende. Noen museer forsøker å gi et inntrykk av liv ved hjelp av plasseringen av objekter (klassisk er det halvt nedbrente vokslyset eller skrivebordstolen som er dratt ut fra bordet, som om forfatteren bare er ute et øyeblikk), eller gjennom portretter og fotografier som viser forfatteren i hjemmet. Noen kan dramatisere forfatteren ved hjelp av skuespillere, enten på video eller i selve museet - på Strindbergsmuseet har man kunnet møte personer utkledd som Strindberg i leiligheten (Bohman 2010:108).

Leiligheten og biblioteket på Strindbergsmuseet viser til Strindberg som biografisk person og kropp, og de fleste moduler i den tematiske utstillingen handler om aspekter ved Strindbergs liv, selv om de gjerne knytter disse til den litterære produksjonen. Strindberg blir også brukt som en linse for å forstå samtiden hans (Bohman 2012:108). Men som vi skal se, er det også andre elementer av den litterære kommunikasjonshandlingen enn AVSENDEREN som inngår i Strindbergsmuseet.

LITTERÆR MEDDELELSE: Hvis forfatteren ikke hadde publisert noe, ville det sannsynligvis ikke vært et museum om henne. Derfor inneholder forfattermuseer ofte den litterære MEDDELELSEN, i form av litterære verk i sin materielle tekstualitet, selv om disse kan forsvinne blant alle biografiske effekter 
(vi må heller ikke glemme at bokutgaver fra forfatterens egen tid også kan være biografiske effekter). Forfatterens tekster kan være tilgjengelige for den besøkende, enten de selges i en gavebutikk eller i noen tilfeller kan leses i selve utstillingen. Museer kan også inneholde litterære tekster i forkortet, fragmentarisk eller indirekte utgave, i form av sitater, synopser eller referanser, og den poetiske funksjonen til slike tekstlige elementer kan vektlegges. Det litterære budskapet kan også omfatte museets omgivelser i form av skilt og utlagte sitat.

På Strindbergsmuseet er den litterære produksjonen mer til stede enn på mange andre forfattermuseer. Mange besøkende vil gå opp bakken i Drottninggatan på veien til museet og se (og kanskje lese) Strindbergsitatene som er lagt inn i gatens overflate. De besøkende må forbi et utsalg med mange av bøkene hans på vei inn i og ut av museet. I den tematiske utstillingen er de fleste modulene utstyrt med en liten bokhylle (fig. 7) med plass til bøker - romaner, skuespill, selvbiografiske verk, politiske skrifter eller fagbøker - som er relevante for modulens tema, og disse kan tas ut og blas i av den besøkende. I tillegg til sitatene i gaten utenfor er også den tematiske utstillingen utstyrt med mange sitater, noen inntegnet på gulvet under modulene.

Selv de mest tradisjonelle forfatterhjemmuseer, der mange av gjenstandene er å finne i hjem bebodd av noen fra samme klasse, samme kultur og samme periode, har nesten allid med en iscenesettelse av den litterære produksjonen eller dens materielle opprinnelsessted, representert i form av penner og/eller skrivemaskiner og skrivebord (Watson 2020), som i Strindbergsmuseet.

LITTERÆR MOTTAKER: En sterk vektlegging av forfatteren eller den litterære AVSENDEREN vil ikke bare sette forfatterskikkelsen foran forfatterens litterære verk, men også foran leseren, den litterære MOTTAKEREN. seum", "lesningsmuseum" eller "lesermuseum" ville sett ut. Gitt at mange forfattere har vært store lesere, finnes det allerede lesermuseer særlig i museer der forfatterens boksamling er bevart som en del av utstillingen (se også Aarbakkes artikkel i dette spesialnummeret) selv om man kan forestille seg at en skrivende forfatter kanskje leser bøker på en annen måte enn andre lesere. En video med museets nåværende direktør Erik Höök betoner at Strindbergs boksamling, som kan besøkes som del av en guidet tur på sin opprinnelige plassering i en annen etasje i huset, først og fremst var en referansesamling som Strindberg brukte i forskning, og ikke som kilde til litterær lesing. Noen litterære museer, f.eks. Jane Austen's House Museum i Chawton i England, inviterer de besøkende til å lese ved å tilby en lesesal. Man må til andre typer litterære utstillinger, først og fremst dem man finner på biblioteker, for at boken skal bli hovedgjenstand i utstillingen.

Selv om Strindbergsmuseet i liten grad handler direkte om hans lesere, handler det delvis om hvordan hans produksjon har blitt brukt, i hvert fall anslagsvis, særlig i moduler om teateroppsetninger og om kommersiell bruk av Strindberg som ikon.

LITTERÆR KONTAKT: Et musealt fokus på enten KONTAKT- eller KODE-funksjonene i den litterære kommunikasjonshandlingen er mindre vanlig. Vi må ofte til bibliotekutstillinger for å finne KONTAKT-funksjonen. I 2014-15 viste Biblioteca Municipal de Santa Cruz de Tenerife en midlertidig utstilling av de mange billige action-, romantikk-, kriminalitets- og science fiction-romanene skrevet på spansk av Pedro Víctor Debrigode Dugi (mange under pseudonym). De fargerike omslagene på bøkene hans, designet for å tiltrekke lesere, sto i fokus, og man kan dermed si at utstillin- 


\section{JOHAN SCHIMANSKI Og ULRIKe SPRING}
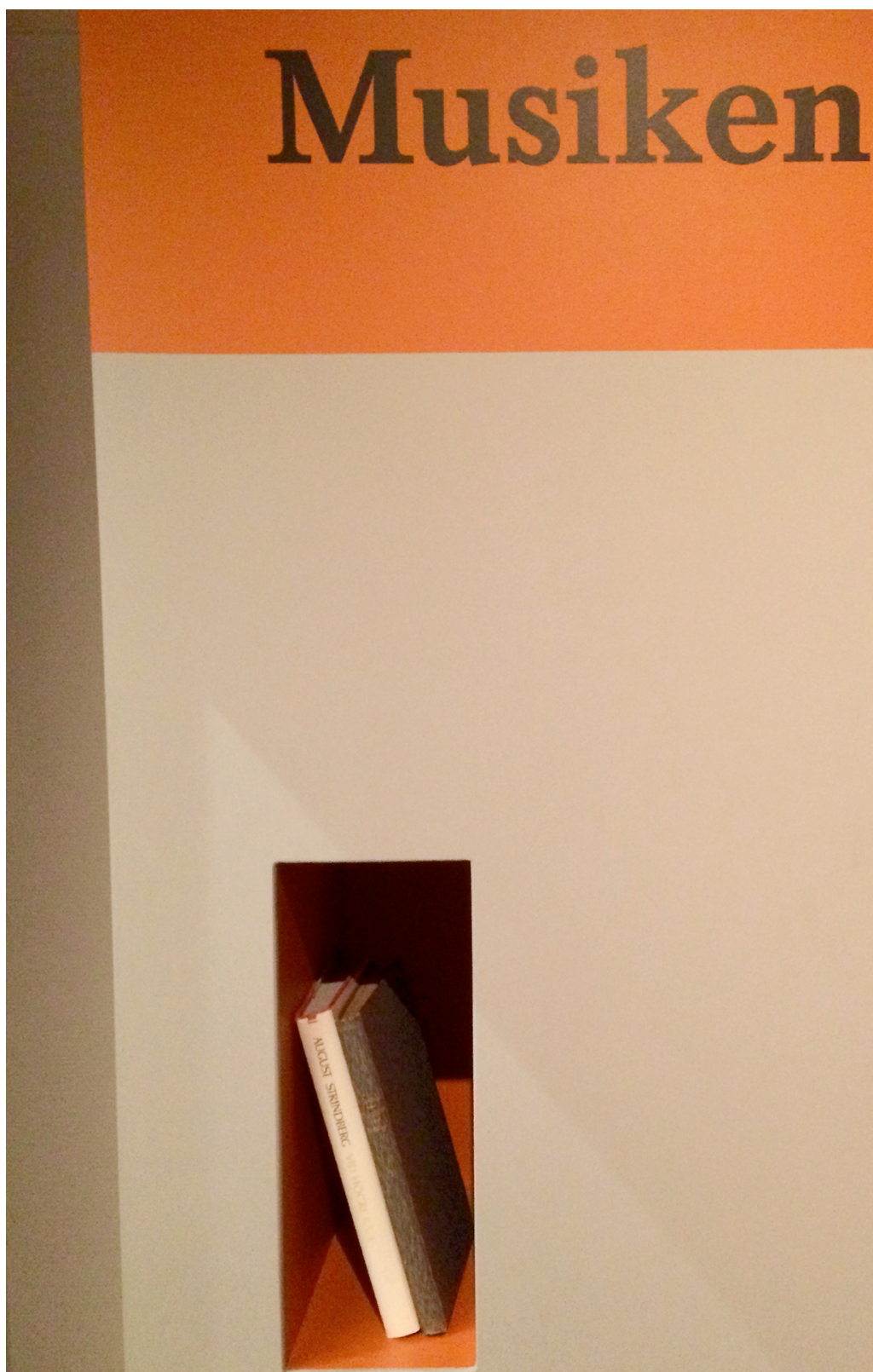

Fig. 7. En av de små bokhyllene i den tematiske utstillingen på Strindbergsmuseet. Foto: Johan Schimanski og Ulrike Spring. 
gen framhevet den litterære KONTAKTEN. Sjangrene som Debrigode Dugi skrev innenfor, er dessuten sjangrer der spenningsfunksjoner, med sine sterke fatiske funksjoner, står primært og har som viktigste oppgave å få leseren til å lese videre.

Denne typen KONTAKT-fokusering kunne vært bedre utnyttet på forfattermuseer og er til dels også til stede på Strindbergsmuseet, f.eks. i den tematiske modulen om teaterstykkene ("Dramatikern"), der mange plakater og annonser er utstilt. Litterær KONTAKT kan også bli spesielt relevant i museer med litterære iscenesettelser, der den besøkende kan få inntrykk av opplevelsen leserne får ved å dykke ned i den litterære verden og dermed tre inn i en annen form for rom som kan være vanskelig å forlate. I Buddenbrooks-huset i Lübeck finnes det to rom som fungerer som "walk-in novel" (Travemünde Lübeck [uten årsangivelse]), som trolig skaper en form for tilstedeværelse i den litterære verden. Det finnes likevel få eksempler på forfattermuseer som fokuserer bevisst på hvordan tekster guider leserne gjennom teksten. På utstillingene i museumshuset som inngår i Moomin Valley Park i utkanten av Tokyo, finner vi "walk-in"-fortellinger som benytter Tove Janssons illustrasjonskunst. Illustrasjonene i Janssons litterære produksjon er en integrert del av fortellingene, særlig i tegneseriene, og de brukes mange steder i museet. En mindre modul antyder hvordan en utstilling kan gi den besøkende innsikt i litteraturens KONTAKT-element: Den viser første rute i mange av tegneseriene, og det går opp for den besøkende at disse alltid inneholder et bilde av hovedpersonen Mummitrollet (Mumintrollet) bakfra, noe som skal skape en spenning og nysgjerrighet hos leseren.

LITTERÆR KODE: Man kan også forestille seg utstillinger med fokus på det litterære KODE-elementet, f.eks. utstillinger der litte- rær teori inntar en sentral plass. UtstillingeParis i 2002-2003 og på Bibliothèque National de France i Paris i 2015, er slike eksempler. Samtidig inneholder enhver litterær tekst en poetikk, en implisitt teori om at det litterære kan være slik denne teksten er (akkurat som et museum allid vil implisere bestemte museologiske forestillinger). Strindbergsmuseet og mange andre litteraturmuseer impliserer en teori om at det dominerende litterære elementet er AVSENDEREN: Litteratur forteller oss om forfatterens livsverden.

LITTERÆR KONTEKST: Litterære museer kan også fokusere på den litterære KONTEKSTEN, dvs. litteraturens beskrivelse av virkelige og/eller fiktive verdener (med virkelige og/eller fiktive personer). Hvordan de besøkende i et forfattermuseum opplever det litterære verkets verden(er) med sine personer, handlinger og idéinnhold, avhenger av hvordan spesifikke litterære verk forholder seg til disse. Museer om f.eks. romantiske naturpoeter vil lettere kunne gi den litterære KONTEKSTEN en ledende rolle, fordi de kan knytte poesien til de virkelige landskapene som de refererer til og som museene er lokalisert i. Slik poesi bekrefter dessuten den sentrale rollen til den litterære AVSENDEREN, poeten som biografisk person og subjektiv dikter. I museer om realistiske forfattere er det enkelt å knytte litterære tekster til den virkelige verdenen som de later til å beskrive på en objektiv måte, med fokus på historiske lag i det landlige eller urbane landskapet og samfunnet som museet befinner seg i. Slike museer kan ligne på historiske museer. Det samme gjelder museer om forfattere som Strindberg, som i tillegg til realistiske romaner også skrev viktige selvbiografiske tekster og samfunnskommentarer. Museer om fantastiske forfattere står overfor andre typer utfordringer. 


\section{MULIGHETER, HINDRINGER OG TVETYDIGHETER I DEN DOBLE KOMMUNIKASJONSMODELLEN}

Både museer og litteratur er kommunikative handlinger, og i sin mest grunnleggende form er et museum om litteratur en presentasjon av en presentasjon, eller en kommunikativ handling om en kommunikativ handling. Denne dobbeltheten er en variant av museets tvetydighet generelt: Museer bruker gjenstander for å fortelle oss om måten disse gjenstandene er brukt på (sml. Scholze 2004:30). I tillegg til forskjellige presentasjonsformer blir besøkende til litterære museer også møtt med en fordobling eller en mangfoldiggjøring av skapere, intensjoner og stemmer. Et museum er vanligvis et produkt av et kurator- og produksjonsteam som arbeider i samspill med andre aktører, men i litterære museer hører man også en annen stemme: forfatterens. Litterære museer forsøker ofte i tillegg å kommunisere en mer privat, indre stemme fra forfatteren. Denne stemmen er ofte ikke hørbar i hans litterære verk, men er gjort eksplisitt i brev, dagbøker, osv. og ofte blandet med forfatterens stemme i eventuelle essays, fagprosa, journalistikk, selvbiografiske tekster og lyrikk. I en museumsverden som er i en demokratiserende bevegelse mot et interaktivt, "cultural hub"-paradigme, bør vi likevel spørre om andre bør kunne komme til orde i et museumsrom som fremdeles domineres av fortellingen om forfatteren.

På den ene siden kan man forsøke å synliggjøre andre i forfatterens livsverden - som ektefeller og andre partnere, barn og andre familiemedlemmer, venner, medarbeidere og i noen tilfeller tjenestefolk - slik som Strindbergsmuseet gjør i bordoppsettinger i leilighetens spisesal og i tematiske moduler om Strindbergs barn og kvinner. På den andre siden finnes litteraturmuseer som har begynt å slippe leserne og de besøkende til orde, noe som er mindre tydelig i Strindbergsmuseets tilfelle (en strategi som Strindbergsmuseet likevel benytter seg av, i likhet med noen andre forfattermuseer, er å arrangere skriveverksteder i lokalene).

Ved hjelp av den doble kommunikasjonsmodellen vi foreslår her, kan posisjonen til kuratorer, forfattere, museer, tekster, besøkende og lesere utforskes og gjøres mer synlig i analysene og i vår forståelse av forfattermuseer. Dermed vil både museologer og museumsarbeidere kunne finne noen mindre opplagte steder der kommunikasjon kan ha en rolle å spille. En strukturert metodologi som ramme for undersøkelser kan gjøre blikkene våre mekaniske og skape nye blinde flekker, men kan også synliggjøre noe uventet.

Om det finnes en blind flekk i Jakobsons modell, er det muligheten for at kommunikasjon kan hindres eller svikter. Imidlertid er dette snarere en påminnelse om at enhver kommunikativ handling innebærer et valg av hva som blir kommunisert og hva som ikke blir kommunisert, samt en usikkerhet om hvordan det kommuniserte mottas. KONTAKT-funksjonen viser dette $\mathrm{i}$ en veldig praktisk forstand. Litterære verk forsøker å trekke inn leserne sine, men klarer ikke alltid å gjøre dette. $\mathrm{Mu}$ seet oppfordrer de besøkende til å gå inn i bestemte rom eller følge en sti, men fraråder eller hindrer besøkende i å gå inn i andre rom, ved hjelp av skilt, vegger, taugjerder, glassflater, låste dører osv. Som i de fleste museer er slike barrierer paradoksalt nok også med på å skape kontaktområder mellom kropp og omgivelser (en vegg er noe man kan henge ting på, et glasskap skaper en fokuseringsramme). De bidrar også til en langsiktig strategi for bevaring og beskyttelse av gjenstander og sikrer KONTAKT med nye besøkende i framtiden.

Museer kan vanskeliggjøre eller hindre til- 
gang ved hjelp av kulturelle grenser, f.eks. når de besøkende ikke kan lese språket som brukes i museet, ikke er kjent med forfatteren eller tilhører minoriteter som ikke føler seg hjemme i museet. Et grunnleggende problem er at litteraturens mediale form og sjangrer gjør det vanskelig å gjøre litteratur tilgjengelig gjennom et museum: Litterære tekster befinner seg oftest i bøker og andre trykksaker som tar tid å lese og normalt ikke er visuelt tilgjengelige i sin helhet. Museer om diktere kan stille ut hele dikt, men lyrisk poesi skaper en språklig barriere for ikke-morsmåltalende på originalspråket, siden den er notorisk vanskelig å oversette. Noen ganger kan også morsmålsbrukere ha vanskeligheter med å lese lyrikk.

Den museale KONTEKSTEN - i hvilken grad museet f.eks. fokuserer på biografi på bekostning av litterære verk - er også et spørsmål om prioritering av ett aspekt foran et annet og dermed en nødvendigvis selektiv fordeling av det som kommuniseres. Det samme gjelder valget av presentasjonsform.

Kommunikative handlinger skaper dessuten nettverk som er mer komplekse enn Jakobsons modell med sine seks elementer eller aktørposisjoner, selv når denne fordobles slik vi foreslår. I en analytisk gjennomgang blir kompleksiteten tydelig, og det er vanskelig å si entydig hvilke av våre standardelementer en bestemt bestanddel i presentasjonen tilhører. Aktører kan "bytte posisjon" i modellen. Vi har allerede sett at forfattere kan være en viktig del av den museale AVSENDEREN. Den besøkende kan inviteres til å skrive selv på museet (som i Wordsworths Dove Cottage i engelske Lake District eller i litteraturmuseet til det østerrikske nasjonalbiblioteket) og dermed innta posisjonen til en litterær AVSENDER. I nesten alle tilfeller vil litterære museer tvinge noen museale MOTTAKERE til å bli litterære, ettersom besøkende som ikke har lest forfatterens bøker, må forestille seg at de er lesere av disse bøkene. Men museal og litterær MOTTAKER av litterære verk og litterære museer er ofte én og samme person. Den litterære AVSENDEREN inntar den litterære MOTTAKERENS rolle når forfatterens aktivitet som leser framtrer: Skrivebord kan suppleres med lesestoler, og som vi har sett iscenesettes forfatterens boksamling i mange forfattermuseer. I noen tilfeller kan litterær KONTEKST bli en del av den museale MEDDELELSEN: Forfattere kan beskrive hjemmene sine i bøkene sine, og disse beskrivelsene kan bli en del av museumsopplevelsen. Skillelinjene mellom litterær og museal KONTEKST overskrides ofte. Forfattermuseer viser til historiske og samfunnsmessige forhold når de presenterer forfatternes livsverdener, og samtidig vil all litteratur forholde seg på direkte eller indirekte vis til verdenen utenfor litteraturen. Strindbergsmuseet benytter seg i utstrakt grad av denne typen overskridelse. Det passer en forfatter som var så engasjert $\mathrm{i}$ politiske, åndelige og samfunnsmessige spørsmål, og et forfatterskap som benyttet seg av så mange former, inkludert journalisme, fagprosa, dagbøker, selvbiografiske skrifter, realisme osv.

Det at aktører kan bytte posisjon i - og mellom - kommunikative handlinger, antyder også en mulighet for at den ene kommunikative handlingen kan inngå i en annen. Vår drøfting av den doble kommunikasjonshandlingen bygger på en idé om at litterære kommunikasjonshandlinger kan inngå som aktive deler i den museale kommunikasjonshandlingen. Men vi kan også snu forholdet på hodet og se på forfattermuseet som en utvidet del av den litterære kommunikasjonshandlingen ( $\mathrm{sml}$. Lund 2016:109). Museet kan bli til en del av den besøkendes lesearbeid. Besøket kan påvirke leserens tolkninger av bestemte litterære tekster eller, når de enda ikke har lest verkene, 
legge rammer for hvordan disse skal kunne tolkes. Forfattermuseet inngår i en utvidet lesekultur som omfatter flere former for litterær MOTTAKELSE, f.eks. litterær turisme, litteraturkritikk og det akademiske studiet av litteratur, samt adapsjoner som filmer, skuespill, tegneserier, illustrasjoner osv. Hvis litterære museer egentlig er en del av lesehandlingen, kollapses den doble museale og litterære kommunikasjonshandlingen til én enkel litterær kommunikasjonshandling.

Artikkelen er basert på forskning som del av forskningsprosjektet TRAUM - Transforming Author Museums, finansiert av Norges forskningsråd (prosjektnummer 251225). Vi vil takke Strindbergsmuseet for tillatelse til å bruke fotografier av utstillingen.

\section{REFERANSER}

Bohman, Stefan 1997. Historia, museer och nationalism. Stockholm: Carlsson.

Bohman, Stefan 2009. "Strindberg i Blå tornet. Ett museum för upplevelse och bildning." Blick. Stockholm då \& nu 5, 88-91.

Bohman, Stefan 2010. Att sätta ansikte på samhällen. Om kanon och personmuseer. Stockholm: Carlsson.

Bohman, Stefan. 2012. "Blå tornet som museum." I Stefan Bohman et al. (red.). Strindberg i Blå tornet. Stockholm: Carlsson, 97-110.

Bohman, Stefan \& Lennart Palmqvist (red.) 2003. Museer och kulturarv. En museivetenskaplig antologi. Stockholm: Carlsson.

Damsholt, Tine \& Dorthe Gert Simonsen 2009. "Materialiseringer. Processer, relationer og performativitet.” I Tine Damsholt, Dorthe Gert Simonsen \& Camilla Mordhorst (red.). Materialiseringer. Nye perspektiver på materialitet og kulturanalyse. Aarhus: Aarhus Universitetsforlag, 9-37.
Hendrix, Harald 2018. "Writers' houses as media of expression and rememberance. From selffashioning to cultural memory." I Harald Hendrix (red.). Writers' Houses and the Making of Memory. New York: Routledge, 1-11.

Hoffmann, Anna Rebecca 2018. An Literatur erinnern. Zur Erinnerungsarbeit literarischer Museen und Gedenkstätten. Bielefeld: transcript.

Jakobson, Roman 1978. "Lingvistikk og poetikk (1960)." I Anders Heldal \& Arild Linneberg (red.). Strukturalisme i litteraturvitenskapen. Artikler av Pjotr Bogatyrjov, Roman Jakobson, Jan Mukařovský, Claude Lévi-Strauss, Jiri Levý, Roland Posner, Jurij Tynjanov, Felix Vodička. Oslo: Gyldendal, 119-157.

Latour, Bruno 2005. Reassembling the Social: An Introduction to Actor-Network-Theory. Oxford: Oxford University Press.

Lund, Niels D. 2016. "Litteraturen og forfatteren på museum. Traditionsformidling udfordret af den stigende musealisering." Nordisk Museologi 1, 101-120.

Mordhorst, Camilla 2009. "Museer, materialitet og tilstedevær." I Tine Damsholt, Dorthe Gert Simonsen \& Camilla Mordhorst (red.). Materialiseringer. Nye perspektiver på materialitet og kulturanalyse. Aarhus: Aarhus Universitetsforlag, 117-142.

Nath, Atanu \& Parmita Saha 2017. "A theoretical positioning of self and social identities as antecedents in cultural-experiential tourism." Academica Turistica 10:2, 115-128.

Scholze, Jana 2004. Medium Ausstellung. Lektüren musealer Gestaltung in Oxford, Leipzig, Amsterdam und Berlin. Bielefeld: transcript.

Strindbergsmuseet 2011. Strindberg $i$ centrum. Strindbergsmuseet. Stockholm: Strindbergsmuseet.

Strindbergsmuseet 2019. "Basutställning." Strindbergsmuseet. https://www. strindbergsmuseet.se/utstallningar/ basutstallning/ (sett 4. september 2020). 
Söderström, Göran 1999. Strindbergs bostad i Blå tornet. Stockholm: Stockholmia.

Travemünde Lübeck [uten årsangivelse]. "Buddenbrook House." Lübeck Travemünde Marketing. http://www.luebeck-tourism.de/ culture/museums/buddenbrook-house.html (sett 13. september 2019).

Waller, Laurie 2017. "Curating actor-network theory. Testing object-oriented sociology in the science museum." Museum \& Society 14:1, 193-206.

Watson, Nicola J. 2020. The Author's Effects: On Writer's House Museums. Oxford: Oxford University Press.

Aarbakke, Thea 2019. Forfattermuseumsfunksjonene. Musealiserte relasjoner mellom liv og litteratur. En studie av Hamsunsenteret, Bjerkebok - Sigrid Undsets hjem og Hauge-senteret. PhD-avhandling. Universitetet i Oslo.

Johan Schimanski, dr.art., professor johan.schimanski@ilos.uio.no
Institutt for litteratur, områdestudier og europeiske språk

Universitetet $i$ Oslo

Postboks 1003 Blindern

NO-0315 Oslo, Norge

www.hf.uio.no/ilos/personer/vit/johanhsc

Ulrike Spring, dr.phil., førsteamanuensis ulrike.spring@iakh.uio.no

Institutt for arkeologi, konservering og historie Universitetet $i$ Oslo

Postboks 1008 Blindern NO-0315 Oslo, Norge www.hf.uio.no/iakh/personer/vit/historie/fast/ ulrikesp

Institutt for samfunnsvitskap Høgskulen på Vestlandet campus Sogndal Postboks 133

NO-6851 Sogndal, Norge 